\title{
Endogenous ADP-ribosylation during development of the prokaryote Myxococcus xanthus
}

\author{
Deborah Eastmant and Martin Dworkin
}

Department of

Microbiology, University of Minnesota, Minneapolis,

MN 55455, USA
Author for correspondence: Martin

We examined endogenous ADP-ribosylation of proteins during the development of the prokaryote Myxococcus xanthus. In vivo and in vitro endogenous ADP-ribosylation of $M$. xanthus proteins was detected and the profile of modified proteins changed during development. Adenosine and nicotinamide inhibited ADP-ribosylation. Nicotinamide stimulated cells at low density to develop, in a manner similar to that previously observed with adenosine. Higher concentrations of nicotinamide inhibited aggregation. The in vivo effects of nicotinamide on developing $M$. xanthus cells correlate with its in vitro effects on ADP-ribosylation and the developmental profile of putative ADP-ribosylation substrates. These results suggest that ADPribosylation may regulate developmental proteins in $M$. xanthus.

Keywords : myxobacteria, Myxococcus xanthus, endogenous ADP-ribosylation, prokaryotic development

\section{INTRODUCTION}

The life cycle of the myxobacteria has led to the suggestion that these prokaryotes may represent nature's first attempt at multicellularity (Shimkets, 1990). Their life cycle includes multicellular group movement during growth, and development into spore-containing fruiting bodies in response to starvation. The developmental programme allows vegetative cells to differentiate into resistant myxospores, which can remain quiescent until favourable growing conditions are sensed. This developmental programme is initiated when three requirements are met: starvation, presence on a solid surface, and a high cell density. Starvation occurs when the level of amino acids (Dworkin, 1963) or the carbon and energy source is depleted (Manoil \& Kaiser, 1980). Presence on a solid surface is required in order for the cells to exhibit gliding motility, which is necessary for aggregation into fruiting bodies (Burchard, 1981). High cell density (Wireman \& Dworkin, 1975) appears to be important for sensing of intercellular signals exchanged during aggregation and sporulation. Additionally, the cell density requirement designates the size of the fruiting body and the appropriate population density for germination.

If all three of the requirements described above are met,

†Present address: Institute of Molecular Biology and Biotechnology, Heraklion, Crete, 71110 Greece. cells begin to aggregate into mounds, where they undergo differentiation into resistant myxospores. Intercellular signalling evidently occurs during the developmental process (Hagen et al., 1978; Kuspa et al., 1986). Several signals have been identified (Kuspa et al., 1992; Kim \& Kaiser, 1990); however, the pathways by which such signals are transduced are not fully described.

In many systems, signal transduction involves covalent modification of proteins, and modifications such as phosphorylation, methylation and ADP-ribosylation affect many different types of enzyme activities. The ADPribosylation reaction is catalysed by a transferase enzyme, which binds NAD and attaches the ADP-ribose moiety to a substrate protein, releasing nicotinamide in the process (Ueda \& Hayaishi, 1985). The best studied ADP-ribosyl transferases are the bacterial toxins that catalyse the ADPribosylation of eukaryotic signal-transducing trimeric GTP-binding proteins (Spangler, 1992; Ui, 1990). These include cholera and pertussis toxins produced by Vibrio cholerae and Bordetella pertussis, respectively.

Examples of endogenous ADP-ribosylation, in which the transferase and the substrate proteins are in the same organism, have been found in both eukaryotes and prokaryotes (Williamson \& Moss, 1990; Lowery \& Ludden, 1988, 1990). In eukaryotes, ADP-ribosylation has been invoked in the regulation of DNA-histone interactions (Kreimeyer et al., 1985), adenylyl cyclase activity (Moss \& Vaughan, 1978), calcium levels (Duncan 
et al., 1988), phototransduction (Falk \& Schloss, 1988), and nitric oxide effects (Brune \& Lapetina, 1988). Dictyostelium discoideum, a eukaryote with a life cycle formally similar to the myxobacteria, contains an ADPribosyl transferase which is activated by nitric oxide and which may be involved in the developmental life cycle (Tao et al., 1992). Although transferase activities and their substrates have been identified in these eukaryotic systems, the physiological roles of the modified substrates remain unknown.

In the prokaryote Rhodospirillum rubrum, the role of ADPribosylation in the regulation of nitrogen fixation has been well characterized (Fu et al., 1990). Two enzymes modulate the ADP-ribosylation state of nitrogenase. A transferase catalyses the ADP-ribosylation reaction and an ADP-ribosyl glycohydrolase catalyses the removal of the ADP-ribose from nitrogenase. Nitrogenase activity is inhibited when the enzyme is ADP-ribosylated (Lowery et al., 1986); Lowery \& Ludden, 1988). Fixed nitrogen, which is the end-product of the reaction which nitrogenase catalyses, activates the transferase and inhibits the ADP-ribosyl glycohydrolase (Fitzmaurice et al., 1989). This tight regulation of the ADP-ribosylation status of nitrogenase is reminiscent of other regulatory modifications such as phosphorylation, in which a kinase and a phosphatase coordinate to regulate the phosphorylation state of a specific substrate. Endogenous ADP-ribosylation occurs in another prokaryote, Streptomyces coelicolor (Peniyige $e t$ al., 1990), as well. Interestingly, this organism also undergoes a developmental programme in response to starvation, and genetic evidence suggests that ADPribosylation may be involved in this process (Ochi et al., 1992).

The objective of the study presented here was to determine whether $M$. xantbus proteins can be ADPribosylated and whether this protein modification plays a role in the development of fruiting bodies.

\section{METHODS}

Growth and development. The $M$. xanthus strain used for all of the experiments described was DK1622, designated MD207 in our laboratory. Vegetative cells were grown in either CT medium, containing $2 \%(\mathrm{w} / \mathrm{v})$ Casitone (Difco), $10 \mathrm{mM}$ $\mathrm{K}_{2} \mathrm{HPO}_{4} / \mathrm{KH}_{2} \mathrm{PO}_{4}, \mathrm{pH} 7 \cdot 6$, and $8.3 \mathrm{mM} \mathrm{MgSO}$, or CTT medium, containing $1 \%(\mathrm{w} / \mathrm{v})$ Casitone, $10 \mathrm{mM}$ Tris $/ \mathrm{HCl}$, $\mathrm{pH} 7 \cdot 6,1 \mathrm{mM} \mathrm{K}_{2} \mathrm{HPO}_{4} / \mathrm{KH}_{2} \mathrm{PO}_{4}$, and $8.3 \mathrm{mM} \mathrm{MgSO}$, at $32{ }^{\circ} \mathrm{C}$ in a gyratory shaker at 300 r.p.m. Submerged development was performed in plastic tissue culture flasks or in plastic 96-well plates according to Kuner \& Kaiser (1982). For development on an agar surface, cells were starved on TPM agar, containing $10 \mathrm{mM}$ Tris $/ \mathrm{HCl}, \mathrm{pH} 7 \cdot 6,1 \mathrm{mM} \mathrm{K}_{2} \mathrm{HPO}_{4}$, $8.3 \mathrm{mM} \mathrm{MgSO}_{4}, 1.5 \%$ (w/v) Bacto agar (Difco) in Petri plates or in metal pans. Cells were grown vegetatively in CTT medium, centrifuged at $12100 \mathrm{~g}$ for $10 \mathrm{~min}$, washed once in TPM liquid medium and finally resuspended in TPM liquid medium at a density of $2 \times 10^{9}$ cells ml $\mathrm{ml}^{-1}$ (unless otherwise stated). Spots of $25 \mu$ of the cell suspension were applied to the agar surface and allowed to dry in a laminar-flow hood. Dried plates were incubated at $32{ }^{\circ} \mathrm{C}$.

In vivo detection of endogenous ADP-ribosylated substrates. Cells were grown in $75 \mathrm{~cm}^{2}$ plastic tissue culture flasks with
CT'T medium containing $0.4 \mu \mathrm{M}\left[8^{-14} \mathrm{C}\right]$ adenosine $(20 \mathrm{nCi}$ per $\mathrm{ml}$ medium, specific activity $50-60 \mathrm{mCi} \mathrm{mmol}^{-1}, 1 \cdot 85-2 \cdot 22 \mathrm{GBq}$ $\mathrm{mmol}^{-1}$; Amersham) for $24 \mathrm{~h}$ at $32^{\circ} \mathrm{C}$. Cells were harvested, resuspended in $50 \mathrm{mM}$ Tris base, $\mathrm{pH} \mathrm{7}$, and lysed by sonication. Cells were centrifuged at $11640 \mathrm{~g}$ for $15 \mathrm{~min}$. The supernatant fluid was mixed with $2 \times$ SDS-PAGE sample buffer $(140 \mathrm{mM}$ Tris, $\mathrm{pH} 6.8,7 \%$, w/v, SDS, $5 \%$, v/v, glycerol, $0.003 \%$ bromophenol blue). Soluble proteins were separated by onedimensional SDS-PAGE and the ${ }^{14} \mathrm{C}$-labelled proteins detected by autoradiography.

In vitro detection of endogenous ADP-ribosylated substrates. Cells were grown, harvested at different times during development and resuspended in an ADP-ribosylation reaction mixture containing $1 \mathrm{mM}$ ATP, $1 \mathrm{mM}$ EDT A, $10 \mathrm{mg}$ pyruvate kinase $\mathrm{ml}^{-1}$ and $3 \mathrm{mM}$ phosphoenol pyruvate. Cells were lysed by sonication and [adenylate- $\left.{ }^{32} \mathrm{P}\right] \mathrm{NAD}$ (specific activity $>200 \mathrm{Ci}$ $\mathrm{mmol}^{-1},>7.4 \mathrm{TBq} \mathrm{mmol}^{-1}$; ICN) was added to a final concentration of $5 \mu \mathrm{M}$. After $45 \mathrm{~min}$ incubation at $32{ }^{\circ} \mathrm{C}, 50 \mathrm{mM}$ Tris base, $\mathrm{pH} 7$ (1.5 times the volume of the reaction sample), was added. Samples were centrifuged at $11640 \mathrm{~g}$ for $15 \mathrm{~min}$. The supernatant fluid was removed and the samples were diluted in $2 \times$ SDS-PAGE sample buffer. The ${ }^{32} \mathrm{P}$-labelled proteins were detected on autoradiographs of the dried SDSPAGE gels. The particulate and soluble proteins were separated on $10 \%$ and $12 \%$ polyacrylamide gels, respectively.

TLC and HPLC analysis of hydrolysed ADP-ribose. In order to determine whether the ${ }^{32} \mathrm{P}$-labelled proteins on two-dimensional gels corresponded to ADP-ribosylated proteins, specific proteins were analysed. Briefly, lysed cell preparations of $M$. xanthus were ADP-ribosylated in the presence of $\left[{ }^{32} \mathrm{P}\right] \mathrm{NAD}$ and separated into pellet and soluble fractions by centrifugation as described above. Samples were prepared for and subjected to two-dimensional electrophoresis as described below. After twodimensional separation, proteins were transferred from the polyacrylamide gel to nitrocellulose in blotting buffer containing $25 \mathrm{mM}$ Tris base, $\mathrm{pH} 8.3,192 \mathrm{mM}$ glycine, and $20 \%$ $(\mathrm{v} / \mathrm{v})$ methanol. An electrical field of $150 \mathrm{~mA}$ was applied for $12 \mathrm{~h}$ to transfer the proteins to the nitrocellulose membrane. Ponceau S (Sigma) was used to visualize the proteins on the membrane. ${ }^{32}$ P-labelled proteins were visualized by autoradiography. Autoradiographs and Ponceau $S$ stained nitrocellulose membranes were compared to determine which proteins on the nitrocellulose corresponded to ${ }^{32} \mathrm{P}$-labelled proteins. The labelled proteins were cut from the nitrocellulose membrane and placed in separate tubes containing $0.1 \mathrm{M}$ $\mathrm{NaOH}$. After $3 \mathrm{~h}$ (TLC) or $8 \mathrm{~h}$ (HPLC) incubation at $37^{\circ} \mathrm{C}$ the supernatant fluid $(0 \cdot 1 \mathrm{M} \mathrm{NaOH})$ was dried under vacuum and rehydrated in $1 \mathrm{mM}$ Tris, $\mathrm{pH}$ 7. For TLC, samples were spotted onto silica gel $\mathrm{G}$ plates (Amicon) containing a fluorescent indicator. Control samples of 10 pmol ADP-ribose and 5'-AMP were also applied to silica gel $G$ plates. The plates were then developed in a pre-equilibrated chamber containing the solvent system of $n$-butanol/acetone/acetic acid/ammonium hydroxide/water (9:5:5:2:1, by vol.). After chromatographic separation the plates were dried and subjected to autoradiography to enable determination of the $R_{F}$ value of the radioactive substance. Control samples of ADP-ribose and $5^{\prime}$ AMP were detected using a short-wave ultraviolet lamp. HPLC analysis of samples was done on a Gilson HPLC instrument using a glass column packed with AG-MPI (a macroporous anion resin, 200-400 mesh, chloride form). A gradient was run using $150 \mathrm{mM}$ trifluoroacetic acid (A) and water (B): $0 \mathrm{~min}=$ $1 \% \mathrm{~B} ; 6 \mathrm{~min}=2 \% \mathrm{~B} ; 11 \mathrm{~min}=4 \% \mathrm{~B} ; 16 \mathrm{~min}=8 \% \mathrm{~B}$; $21 \mathrm{~min}=16 \% \mathrm{~B} ; 26 \mathrm{~min}=32 \% \mathrm{~B} ; 26.1 \mathrm{~min}=100 \% \mathrm{~B}$. Standards of $5^{\prime}$-AMP and ADP-ribose were run and detected spectrophotometrically at $254 \mathrm{~nm}$. Sample fractions were col- 
lected every $2 \mathrm{~min}$ and their radioactivity measured in a scintillation counter.

Two-dimensional gel analysis of ADP-ribosylated proteins. In order to further characterize the endogenously ADPribosylated proteins, vegetative cells and cells undergoing development were harvested, ADP-ribosylated using $\left[{ }^{32} \mathrm{P}\right] \mathrm{NAD}$, and fractionated by centrifugation in the same manner as samples that were subjected to one dimensional SDSPAGE. However, for two-dimensional separation the supernatant was diluted $2: 1$ with isoelectric focusing sample buffer (9.5 M urea, 2\% (w/v) pH 3-10 ampholines (Bio-Rad), 5\% (v/v) $\beta$-mercaptoethanol) and loaded on to tube gels to begin the process of separation according to the method of O'Farrell (1975).

Inhibition of endogenous ADP-ribosylation with nicotinamide and adenosine. Cells grown in CTT medium were lysed by sonication after being centrifuged and resuspended in ADPribosylation reaction mixture (see in vitro ADP-ribosylation procedure above) alone, or ADP-ribosylation reaction mixture containing $1 \mathrm{mM}$ adenosine, or ADP-ribosylation reaction mixture containing $50 \mathrm{mM}$ nicotinamide. The reaction was allowed to proceed for $45 \mathrm{~min}$ at $32^{\circ} \mathrm{C}$. The samples were prepared for SDS-PAGE and proteins were separated onedimensionally, as described above. ADP-ribosylated substrates were detected by autoradiography.

Effect of nicotinamide on development. Cells were prepared for submerged development in 96-well plates with MOPS/salts medium as described above. Nicotinamide at concentrations from $50 \mu \mathrm{M}$ to $50 \mathrm{mM}$, in MOPS/salts medium, was added to separate sets of wells. Plates were incubated at $32{ }^{\circ} \mathrm{C}$ and were observed after $24 \mathrm{~h}$. In order to determine whether the effect of nicotinamide was reversible, the medium from all wells was removed and cells were washed twice with fresh MOPS/salts medium. After washing, fresh MOPS/salts medium was added to all wells and plates were incubated another $48 \mathrm{~h}$ at $32^{\circ} \mathrm{C}$.

Low cell density development. The effect of nicotinamide on cells at low densities was tested. TPM agar containing $50 \mu \mathrm{M}$ nicotinamide, $50 \mu \mathrm{M}$ adenosine or no addition was prepared and poured into Petri plates. $M$. xantbus cells were grown in CTT medium and centrifuged. After resuspension in TPM liquid medium at a density of $2 \times 10^{9}$ cells $\mathrm{ml}^{-1}$, a twofold dilution series was prepared. Cell suspensions $(25 \mu \mathrm{l})$ at each density were spotted on to TPM, nicotinamide-TPM, and adenosine-TPM plates. Spotted cells were dried for $30 \mathrm{~min}$ in a laminar-flow hood. Plates were incubated at $32{ }^{\circ} \mathrm{C}$ for $3-7 \mathrm{~d}$ and the number of aggregates per $\mathrm{cm}^{2}$ was determined.

\section{RESULTS}

\section{Detection of endogenous ADP-ribosylation in $\boldsymbol{M}$. xanthus}

To detect ADP-ribosylated substrates, lysed cell preparations were incubated with [adenylate- $\left.{ }^{32} \mathrm{P}\right] \mathrm{NAD}$ in vitro. After centrifugation to separate membrane-associated substrates from soluble substrates, samples were subjected to SDS-PAGE and autoradiography. At least five substrates, with apparent molecular masses of $66,48,44,37$ and $29 \mathrm{kDa}$, were found in the particulate fraction after centrifugation (Fig. 1, lane 1). These substrates may be associated with either the outer membrane, the cytoplasmic membrane or the extracellular matrix. In the soluble fraction at least five additional substrates, with molecular masses of $50,45,43,40$ and $31 \mathrm{kDa}$, were detected (Fig. 1, lane 2). To further verify the endogenous ADP-ribosylation of these $M$. xanthus substrates, in vivo experiments were performed using [8$\left.{ }^{14} \mathrm{C}\right]$ adenosine. Clear bands of labelled soluble proteins with molecular masses of 50 and $31 \mathrm{kDa}$, as well as a fuzzy band between 40 and $45 \mathrm{kDa}$ (most likely corresponding to two or more proteins), were detected (Fig. 2). Adenosine is a precursor in histidine biosynthesis and we cannot rule out the possibility that the label detected is that incorporated into histidine in the in vivo experiments; however, the common molecular masses of the ${ }^{14} \mathrm{C}$ - and ${ }^{32} \mathrm{P}$-labelled soluble proteins suggest that these proteins are indeed ADP-ribosylated.

\section{Identification of the modification as ADP-ribose}

Since the NAD utilized in in vitro experiments was adenylate labelled and may have been contaminated with $\left[{ }^{32} \mathrm{P}\right]$ ATP, it was possible that the modification observed represented adenylylation. In order to determine whether the modification detected with $\left[{ }^{32} \mathrm{P}\right] \mathrm{NAD}$ was ADPribose or adenylate, the putative $\left[{ }^{32} \mathrm{P}\right] \mathrm{ADP}$-ribosylated

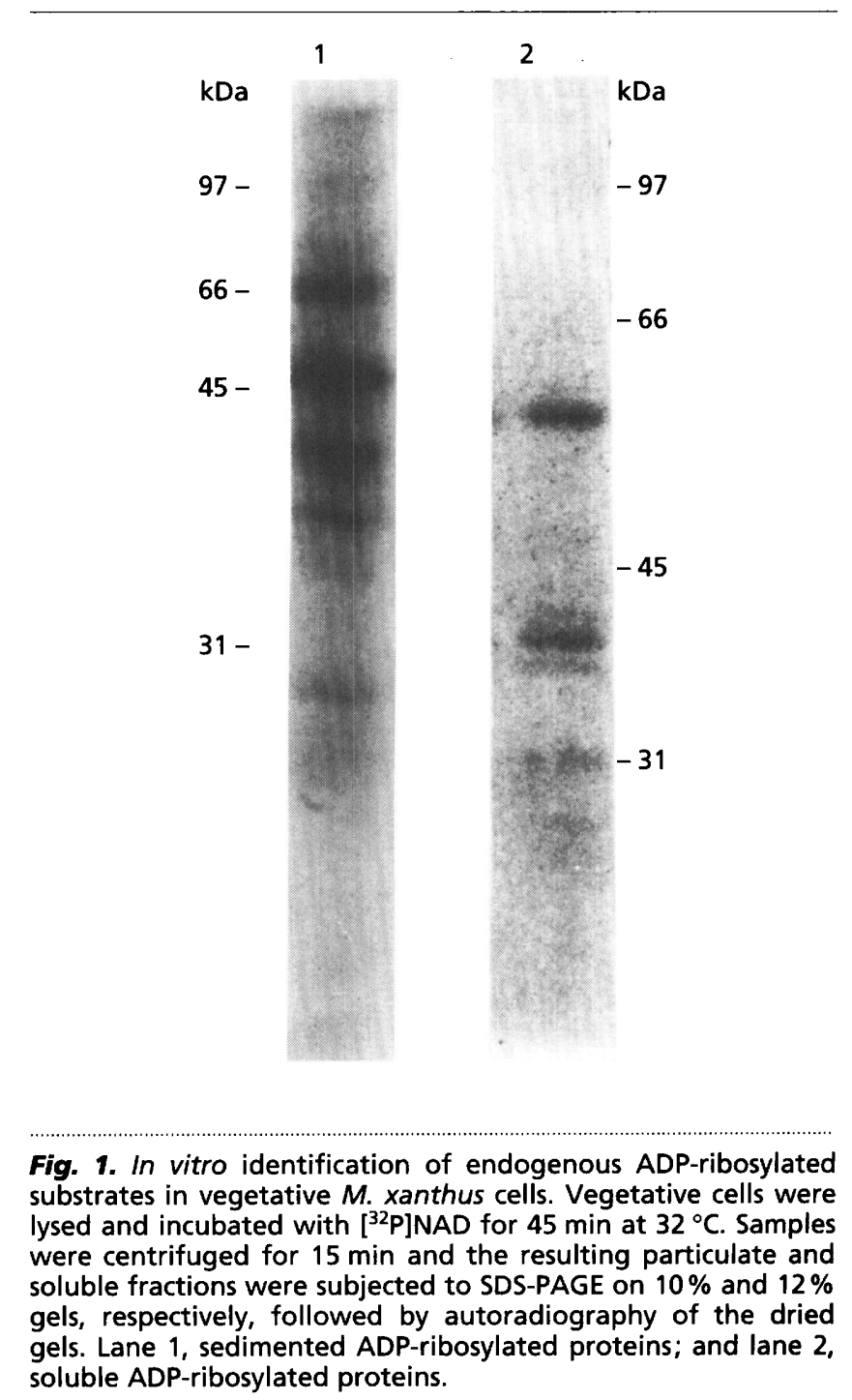




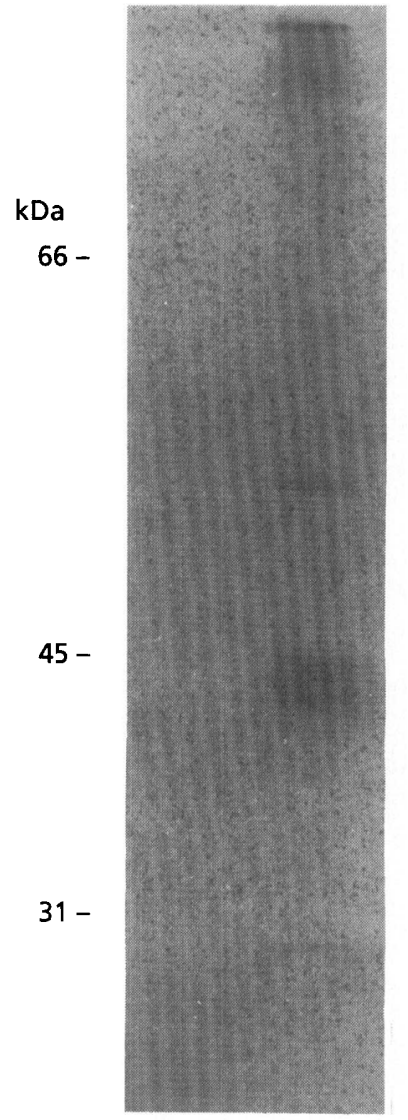

Fig. 2

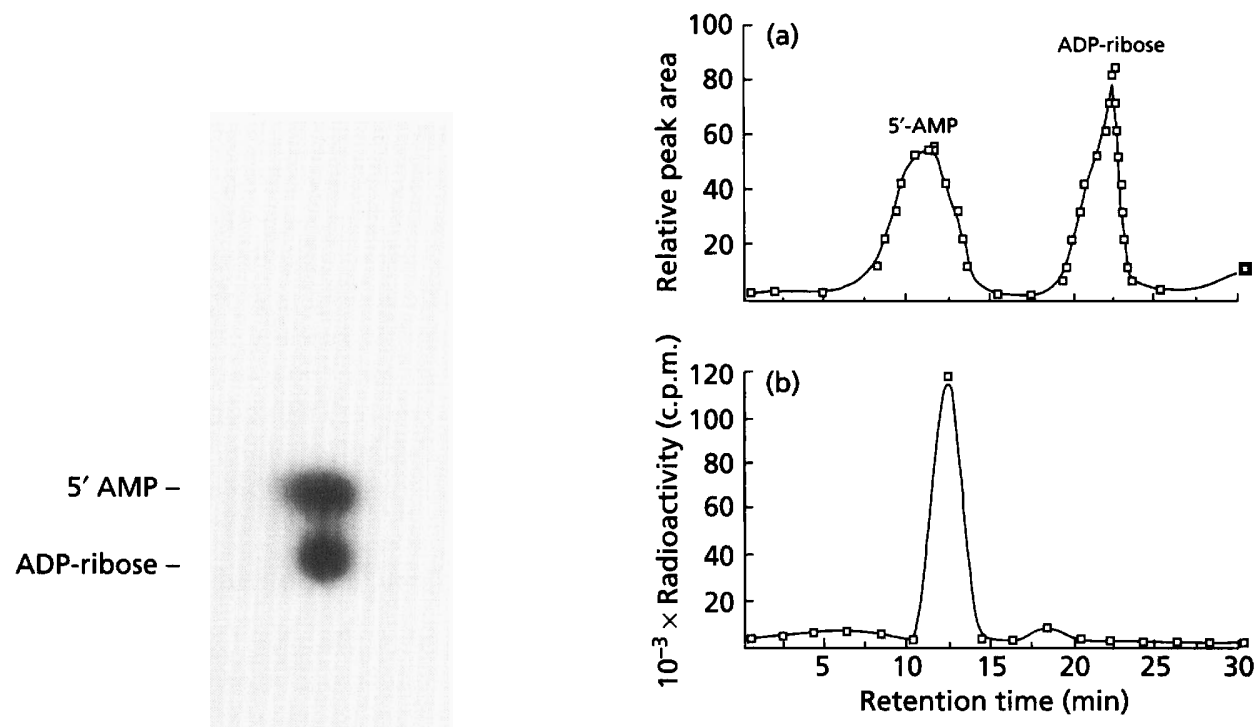

Origin -

Fig. 3

Fig. 2. In vivo identification of endogenous ADP-ribosylated soluble substrates in vegetative $M$. xanthus cells. $M$. xanthus cells were grown in $75 \mathrm{~cm}^{2}$ plastic tissue culture flasks in CTT medium containing $\left[{ }^{14} \mathrm{C}\right.$ ]adenosine. After $24 \mathrm{~h}$ the cells were harvested and lysed by sonication. Lysed cell preparations were centrifuged for $15 \mathrm{~min}$ and the soluble fraction was subjected to SDS-PAGE on $12 \%$ gels followed by autoradiography.

Fig. 3. Identification of modification as ADP-ribose: TLC. [32p]ADP-ribosylated vegetative proteins were separated by two-dimensional gel electrophoresis and transferred to nitrocellulose. The labelled proteins were then detected by autoradiography of the nitrocellulose membrane and the protein spot corresponding to one of the [32P]ADP-ribosylated proteins ( $43 \mathrm{kDa}$ soluble) was cut out from the rest of the nitrocellulose membrane. The protein was treated with $0.1 \mathrm{M}$ $\mathrm{NaOH}$ for $3 \mathrm{~h}$ at $37^{\circ} \mathrm{C}$ and the supernatant was subjected to one-dimensional TLC. An autoradiograph of the TLC plate is shown.

$43 \mathrm{kDa}$ protein was treated with $0 \cdot 1 \mathrm{M} \mathrm{NaOH}$ for $3 \mathrm{~h}$ at $37^{\circ} \mathrm{C}$ and the hydrolysed products were subjected to TLC. NAD, ADP-ribose and 5'-AMP (a hydrolysed product of ADP-ribose) standards were also chromatographed and detected by UV. The results demonstrated that ADP-ribose and $5^{\prime}$-AMP were released by hydrolysis (Fig. 3). HPLC analysis of ${ }^{32}$ P-labelled samples subjected to alkaline hydrolysis confirmed the TLC results. $\mathrm{Hy}-$ drolysis of the HPLC samples was increased from 3 to $8 \mathrm{~h}$ to increase the concentration of released product. Under
Fig. 4. Identification of modification as ADP-ribose: HPLC. [ ${ }^{32}$ P]ADP-ribosylated vegetative proteins were separated by two-dimensional gel electrophoresis and transferred to nitrocellulose. The labelled spots were detected by autoradiography of the nitrocellulose membrane and the protein spot corresponding to the $43 \mathrm{kDa}{ }^{32} \mathrm{P}$-labelled protein was cut from the rest of the nitrocellulose membrane. The protein was treated with $0.1 \mathrm{M} \mathrm{NaOH}$ for $8 \mathrm{~h}$ at $37^{\circ} \mathrm{C}$ and the supernatant was subjected to HPLC. (a) ADP-ribose and 5'-AMP standards. (b) ${ }^{32}$ p-labelled products hydrolysed from the $M$. xanthus protein.

these conditions $1 \mathrm{mM}$ ADP-ribose is completely hydrolysed to $5^{\prime}$-AMP (data not shown). Although there was not enough sample to detect the putative ADP-ribose and $5^{\prime}$ AMP spectrophotometrically, radiodetection of the ${ }^{32} \mathrm{P}$ labelled fractions from the column showed that a major peak of radioactivity had a similar retention time as the $5^{\prime}$ AMP standard, $11 \cdot 3$ min (Fig. 4). Two small peaks of radioactivity were detected in fractions collected at 17.5 and between 4 and $8 \mathrm{~min}$; however, we do not know what these counts represent. These data suggest that, under these hydrolysis conditions, 5'-AMP was the major radiolabelled product recovered, as expected (Fig. 4b). The detection of ADP-ribose by TLC and HPLC verifies that the modification of the $43 \mathrm{kDa}$ protein is ADPribosylation, not adenylylation, and suggests that the other ${ }^{32} \mathrm{P}$-labelled proteins in our in vitro assay are also ADP-ribosylated.

\section{ADP-ribosylation profile during development}

In order to determine whether ADP-ribosylation is involved in the process of fruiting body formation in $M$. xantbus, we examined ADP-ribosylation levels at different stages of $M$. xanthus development. Submerged cells undergoing development were harvested at different times after the initiation of development. ADP-ribosylated substrates were detected by incubation of the lysed cells with $\left[{ }^{32} \mathrm{P}\right] \mathrm{NAD}$. Two-dimensional SDS-PAGE analysis revealed that prior to starvation, five major soluble 

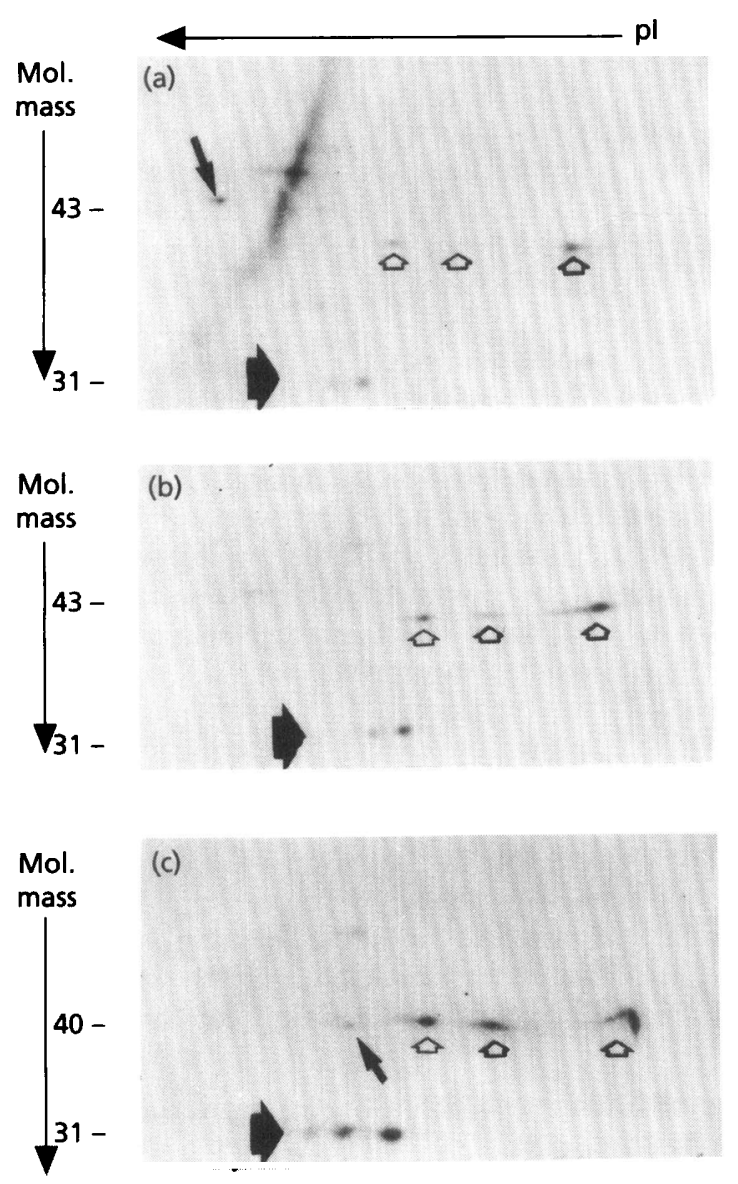

Fig. 5. Two-dimensional separation of soluble ADP-ribosylated proteins during development. Cells were grown overnight in CTT medium in plastic tissue culture flasks. Development was initiated and cells were harvested at different times of development, lysed and incubated with [32P]NAD. After centrifugation, soluble proteins were subjected to twodimensional gel electrophoresis and autoradiography. Autoradiographs are presented here. (a) Vegetative cells; (b) cells after $6 \mathrm{~h}$ development; (c) cells after $13 \mathrm{~h}$ development.

proteins, with molecular masses of $50,45,43,40$ and $31 \mathrm{kDa}$, were ADP-ribosylated (Fig. 5). The $50 \mathrm{kDa}$ ADP-ribosylated protein detected in one-dimensional gel electrophoresis apparently has a $\mathrm{pI}$ above 9 or below 4 since it was not detected on the two-dimensional gels. An unidentified radioactive 'streak' was detected on several autoradiographs at all time points, but could not be detected reproducibly. Further inspection of the autoradiographs confirmed that differential regulation of ADP-ribosylation of soluble $M$. xanthus proteins occurred. The $43 \mathrm{kDa}$ spot decreased in intensity at $6 \mathrm{~h}$ and was no longer detectable at $13 \mathrm{~h}$ of development (Fig. 5a, see fine arrow). The $40 \mathrm{kDa}$ band detected on onedimensional SDS-PAGE appears to be composed of three proteins which have different isoelectric points (Fig. 5a, open arrows). One of these spots was barely visible at $0 \mathrm{~h}$ (Fig. 5a, middle open arrow). All three species increased in intensity at 6 h (Fig. 5b, open arrows) and 13 h (Fig. 5c,

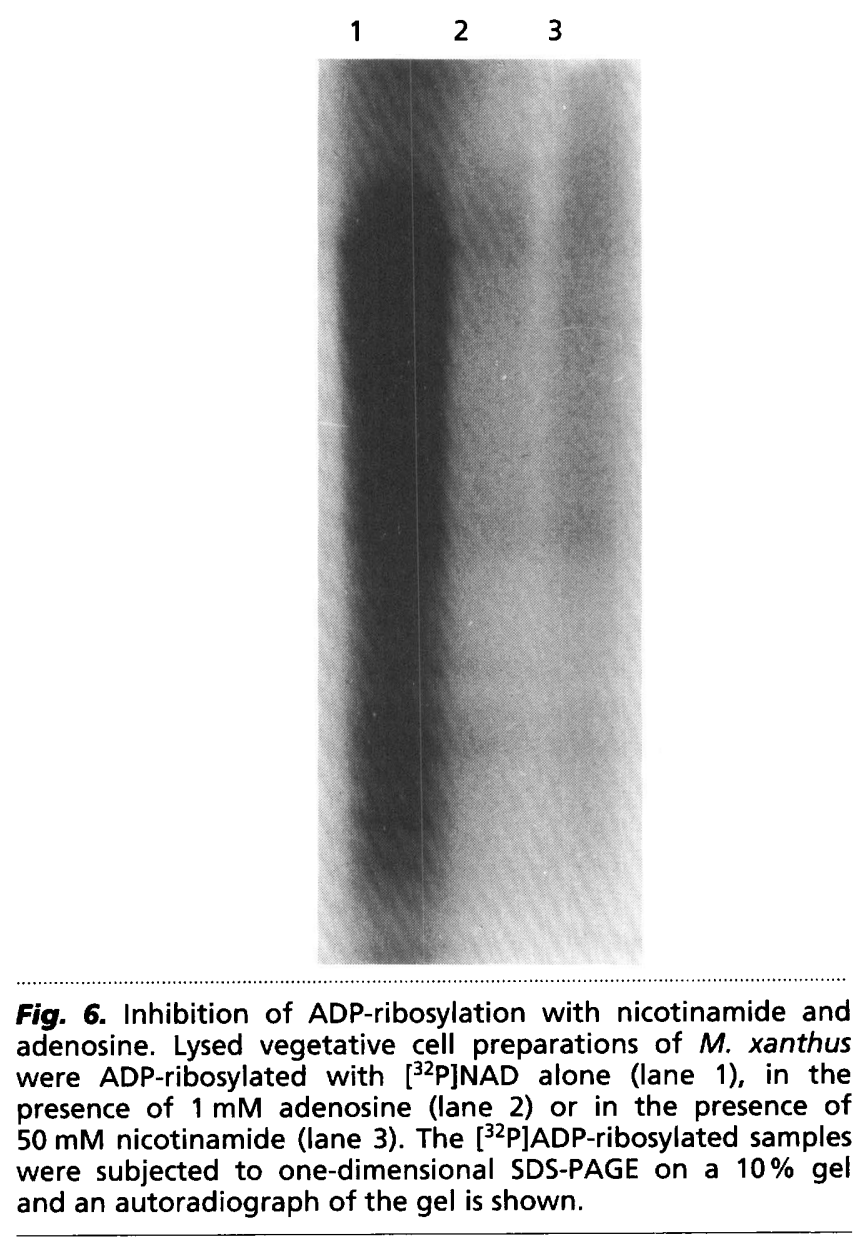

open arrow) of development, as did the $40 \mathrm{kDa}$ band in the one-dimensional gels (data not shown). A new spot at $38 \mathrm{kDa}$ was detected at $12 \mathrm{~h}$ of development (Fig. 5c, thin arrow). Interestingly, the $30 \mathrm{kDa}$ proteins appeared to have a pattern of change similar to the $40 \mathrm{kDa}$ proteins, since only two of the $30 \mathrm{kDa}$ spots were present early in development and the intensity of these spots increased later at $6 \mathrm{~h}$ (Fig. 5b, broad filled arrow) and $13 \mathrm{~h}$ (Fig. 5c, broad filled arrow). Thus, the profile of ADP-ribosylated proteins changes during fruiting body development.

\section{Inhibition of ADP-ribosylation with nicotinamide and adenosine}

Nicotinamide and adenosine have both been shown to be competitive inhibitors of ADP-ribosyl transferases (Williamson \& Moss, 1990). The inhibitory coefficients of adenosine and nicotinamide on diphtheria toxin ADPribosylation of elongation factor 2 (EF2) are very similar and it is believed that both are able to bind to the NAD binding site to compete with NAD (Chung \& Collier, 1977). The effects of adenosine and nicotinamide on $M$. xanthus endogenous ADP-ribosylation were tested by adding them to lysed cell preparations in the presence of $\left[{ }^{32} \mathrm{P}\right]$ NAD. Both adenosine (Fig. 6, lane 2) and nicotinamide (Fig. 6, lane 3) inhibited ADP-ribosylation as judged by autoradiographs. The wells were deliberately 


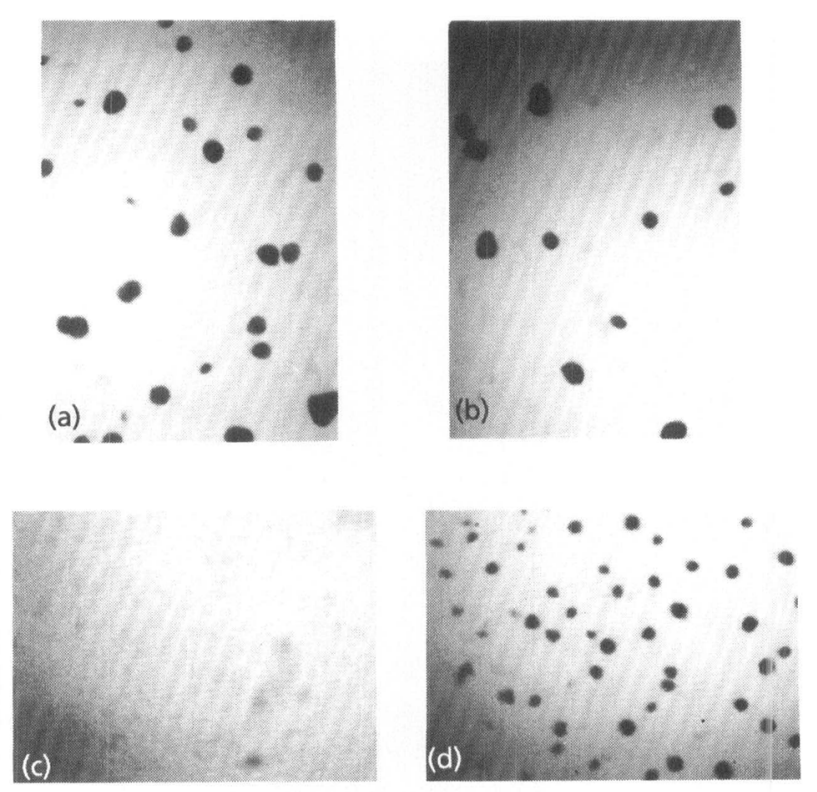

Fig. 7. Reversal of the inhibitory effect of nicotinamide on development. Cells were allowed to develop in MOPS/salts medium in 96-well plates as described in Methods. Cells in several wells which had been treated with $50 \mathrm{mM}$ nicotinamide for $24 \mathrm{~h}$ were washed with fresh MOPS medium and were incubated for another $48 \mathrm{~h}$ in the presence of fresh MOPS medium without added nicotinamide. Fruiting bodies in (a) MOPS alone, (b) MOPS $+50 \mathrm{mM}$ pyridine, (c) MOPS $+50 \mathrm{mM}$ nicotinamide, (d) MOPS $+50 \mathrm{mM}$ nicotinamide removed after $24 \mathrm{~h}$ are shown.

overloaded to increase the likelihood of detecting any radioactive bands present at low levels in lanes 2 and 3 .

\section{Effect of nicotinamide on development}

Since nicotinamide inhibited ADP-ribosylation in lysed cell preparations of $M$. xanthus, the effects of nicotinamide on fruiting body development were examined. Nicotinamide at varying concentrations $(10 \mu \mathrm{M}-50 \mathrm{mM})$ was added to cells undergoing submerged development. Addition of high concentrations $(10$ and $50 \mathrm{mM})$ of nicotinamide resulted in inhibition of aggregation (data not shown). Cells were also treated with the same concentration of pyridine, which is structurally similar to nicotinamide, to determine whether the inhibition was due to non-specific effects. Untreated and pyridine-treated cells aggregated normally by $24 \mathrm{~h}$ (Fig. 7), whereas no aggregation was apparent in the cells treated with high concentrations of nicotinamide. After $24 \mathrm{~h}$ the MOPS/ salts medium was removed from all cells and replaced with fresh MOPS/salts medium. Cells were allowed to incubate for a further $48 \mathrm{~h}$. Removal of nicotinamide from the medium resulted in recovery of aggregation (Fig. 7). This suggests that the inhibitory effect of nicotinamide on development was not due to cell killing or other general toxic effects, rather that nicotinamide inhibited an activity, most probably ADP-ribosylation, which is required for aggregation. Further controls were done to determine the effects of nicotinamide on $M$. xanthus growth and development. The doubling time was not affected by nicotinamide at any concentration tested (data not shown). Since starvation is a requirement for aggregation and subsequent developmental events, nicotinamide was tested for its ability to support growth of cells in MOPS/salts medium. No growth was observed after $72 \mathrm{~h}$ incubation in this medium (data not shown).

\section{Rescue of low cell density development with nicotinamide}

In addition to the inhibitory effect of high concentrations of nicotinamide on aggregation, an opposite effect of low concentrations of nicotinamide was also observed. Interestingly, a subtle stimulatory effect was observed in cells undergoing submerged development (data not shown). This effect was clearly visible when cells were plated at a lower cell density $\left(2 \times 10^{7}\right.$ cells per $\left.\mathrm{cm}^{2}\right)$ on agar containing $50-100 \mu \mathrm{M}$ nicotinamide. After $3 \mathrm{~d}$ incubation, aggregates were not detected on unsupplemented agar (Fig. 8a); however, aggregates were present on agar plates containing nicotinamide (Fig. 8b). At this density (a)

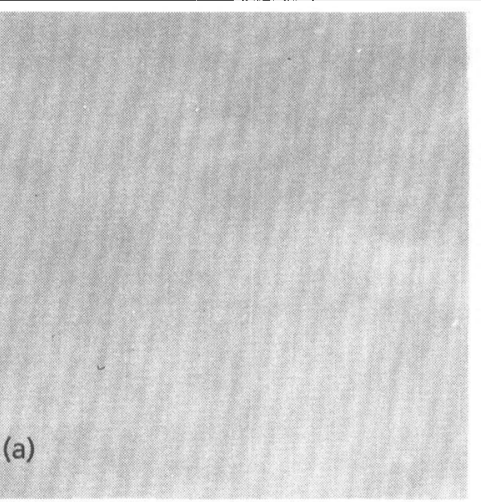

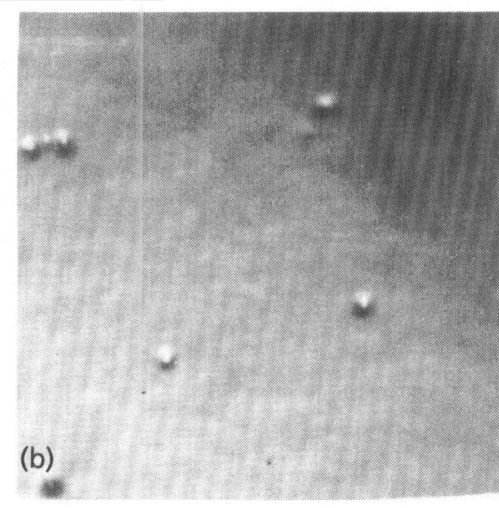

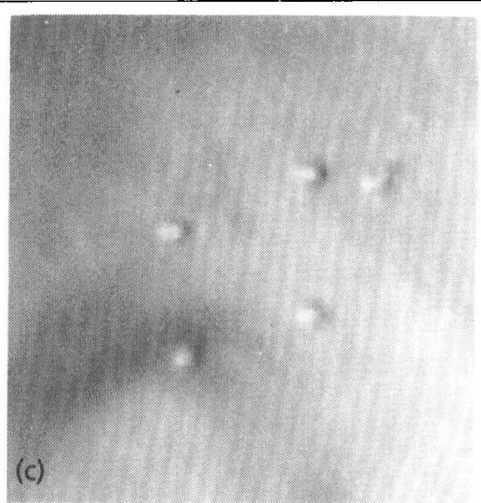

Fig. 8. Stimulation of development with low concentrations of nicotinamide. Cells were plated on TPM agar (a), TPM agar $+50 \mu \mathrm{M}$ nicotinamide (b), and TPM agar $+50 \mu \mathrm{M}$ adenosine (c). Plates were incubated for $3 \mathrm{~d}$. Aggregates formed under each of these conditions are shown. 


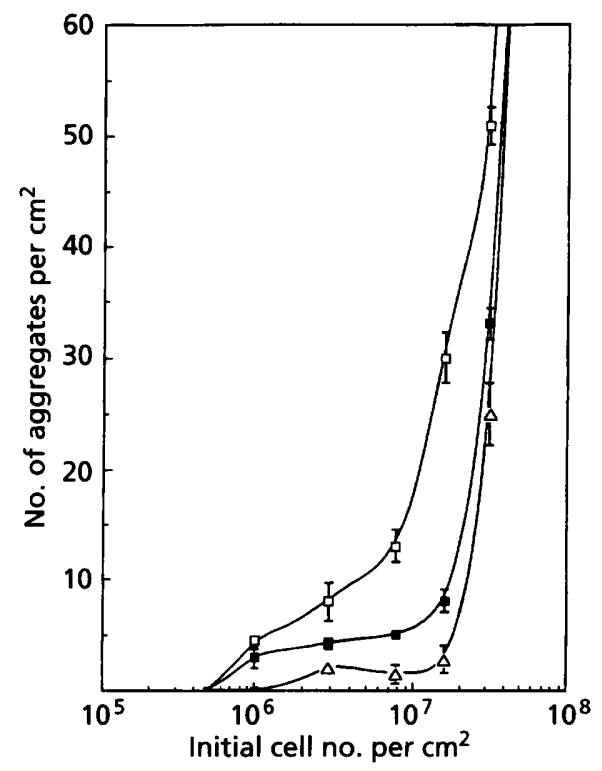

Fig. 9. Rescue of development at low cell density with nicotinamide. Cells were plated on TPM agar ( $\triangle$ ). TPM agar $+50 \mu \mathrm{M}$ nicotinamide $(\square)$, or TPM agar $+50 \mu \mathrm{M}$ adenosine $(\boldsymbol{G})$ at different cell densities. After $5 \mathrm{~d}$ incubation at $32^{\circ} \mathrm{C}$ the number of aggregates per $\mathrm{cm}^{2}$ was counted using a dissecting microscope. The results are means $(n=3) \pm$ SEM.

untreated cells will form fruiting bodies approximately $2 \mathrm{~d}$ later. Since adenosine has been shown to stimulate aggregation of $M$. xanthus cells at low density (Shimkets \& Dworkin, 1981), cells were plated on agar containing $50 \mu \mathrm{M}$ adenosine and incubated for $3 \mathrm{~d}$. Aggregates were also detected on these plates (Fig. 8c). This suggested that nicotinamide and adenosine may effect a second ADP- ribosylation process during development. In this case, inhibition of ADP-ribosylation results in stimulation of development.

Since it has been shown that adenosine stimulates development of low density cells and we found that adenosine inhibits ADP-ribosyl transferase activity in $M$. xanthus, it is possible that the in vivo effects observed with adenosine and nicotinamide may correspond to inhibition of a specific ADP-ribosyl transferase. To further analyse this, nicotinamide was tested for its ability to affect development at different cell densities and these effects were compared to those observed with the same concentration of adenosine. Cells were plated at densities from $5 \times 10^{5}$ to $10^{8}$ cells per $\mathrm{cm}^{2}$ on TPM agar with or without the compounds (nicotinamide or adenosine). After $5 \mathrm{~d}$ incubation, aggregates were counted for each of the plated cell densities. The results showed that at cell densities which were incapable of supporting development $\left(5 \times 10^{5}\right.$ to $\left.2 \times 10^{7}\right)$ the addition of nicotinamide, like adenosine, allowed aggregation to occur (Fig. 9). The effect with nicotinamide was even greater than that observed with adenosine.

\section{DISCUSSION}

The evidence reported here suggests that ADP-ribosylation is involved in the development of fruiting bodies in $M$. xanthus. Endogenous ADP-ribosylation is a covalent modification that affects enzyme activities. This regulatory mechanism, in contrast to phosphorylation and methylation, was discovered relatively recently and has been clearly demonstrated for only a few enzyme activities (Chung \& Collier, 1977; Lowery et al., 1986; Ueda \& Hayaishi, 1985). It is possible that ADP-ribosylation plays as central a role as other protein modifications in

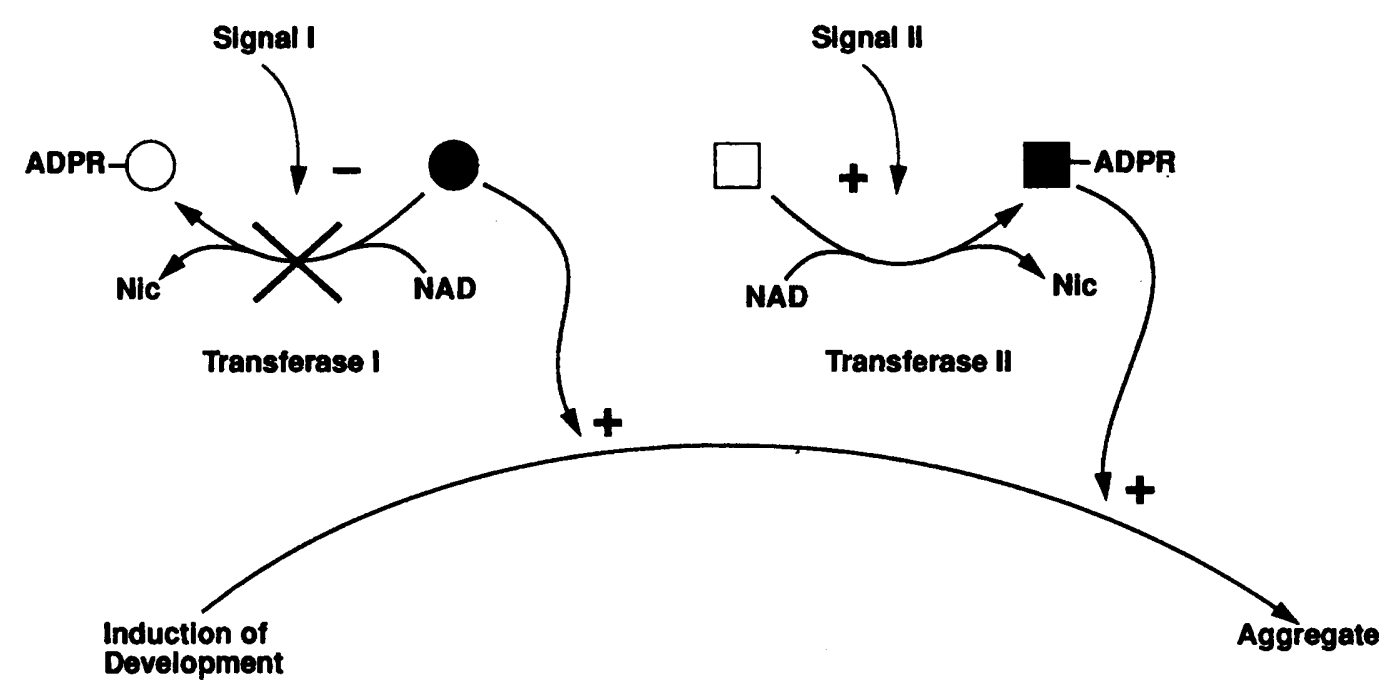

Fig. 10. Model of endogenous ADP-ribosylation events during $M$. xanthus development. 
responding to signals in order to alter substrate activities and ultimately to affect cell processes such as development.

Although ADP-ribosylated substrates were detected in both the soluble and particulate fractions after centrifugation, the focus of the studies presented here was only on the soluble substrates. We now have evidence (unpublished results) that the ADP-ribosylated substrates in the particulate fraction are localized in the extracellular fibrils (Behmlander \& Dworkin, 1991). The changes in the soluble ADP-ribosylated proteins observed during $M$. xanthus development correlate with the effects of nicotinamide on developing cells. These results prompt us to hypothesize that at least two ADP-ribosylation events occur during development in $M$. xanthus. A stochastic model of how these events may regulate developmental processes is shown in Fig. 10. The first ADP-ribosylation event corresponds to the stimulation of development, since cells at a low density are rescued by low concentrations of nicotinamide (and also by adenosine). Nicotinamide is a competitive inhibitor of ADP-ribosyl transferases. Thus, in order to explain the positive effect of nicotinamide on development, inhibition of the ADPribosylation of a specific protein (such as p43) would occur during the early stages of development. We have no information about the identity of the physiological inhibitor of the ADP-ribosylation. However, it has been suggested that A-factor (which is a mixture of amino acids and peptides) acts as a cell-density signal (Kuspa et al., 1992) and it is possible that the A-factor pathway could be involved in ADP-ribosyl transferase inhibition. If this model is correct it would be expected that a protein that was ADP-ribosylated during vegetative growth would no longer be detected as an ADP-ribosylated substrate during development. Indeed, this is consistent with what was detected in the ADP-ribosylation profile of lysed cell preparations harvested at different times during development, since p43-ADP-ribose was lost at $4 \mathrm{~h}$ after the initiation of development. The second proposed ADPribosylation event occurs prior to aggregation, since high concentrations of nicotinamide inhibited aggregation. These results suggest that ADP-ribosyl transferase activity is required early in development and that if the activity is inhibited, development is blocked. According to this model, an increase in ADP-ribosylated substrates or the presence of new ADP-ribosylated substrates will be detected in cells harvested 8 to $12 \mathrm{~h}$ after the initiation of development, since aggregation is apparent at $8 \mathrm{~h}$ and peaks around $12 \mathrm{~h}$. The ADP-ribosylation profile of developmental cells showed that the soluble $40 \mathrm{kDa}$ ADPribosylated protein(s) increased and a new, soluble $38 \mathrm{kDa}$ ADP-ribosylated protein appeared during aggregation. The ADP-ribosylation of these specific proteins may be required for aggregation to occur. In order to aggregate, cells must be motile, thus one mechanism of aggregation regulation may be to ADP-ribosylate proteins necessary for gliding motility. In order to test this it will be interesting to determine whether nicotinamide or adenosine have an effect on gliding motility in M. xantbus.

Wireman \& Dworkin (1975) discovered that high cell densities are required for $M$. xantbus to construct fruiting bodies. Since the myxobacteria move very slowly, diffusion may greatly affect their ability to recognize and respond to extracellular signals (Shimkets, 1990). A high cell density ensures that cells are close to one another, thus decreasing the possibility that signals sent between cells are lost to diffusion. The cell density requirement is bypassed when adenosine is added to the starvation media (Shimkets \& Dworkin, 1981). This suggests either that adenosine is a signal itself or that it affects a signalling pathway which is involved in cell-density regulation. Adenosine itself may be a signal since it is excreted during development and accumulates to a concentration $(6.7 \mu \mathrm{M})$ which is adequate to induce aggregation foci in cells at low densities (Shimkets \& Dworkin, 1981). However, this concentration only induces about $30 \%$ of the total expected aggregation foci and only about $10 \%$ of the expected fruiting bodies, suggesting either that adenosine is not the physiological signal or that additional signals are involved in the process (Shimkets \& Dworkin, 1981). Since adenosine inhibits ADP-ribosyl transferase activity it is possible that adenosine's effects on cell density development are, at least in part, due to this inhibition. This hypothesis is supported by the finding that nicotinamide, like adenosine, is both an inhibitor of ADPribosyl transferase activity and an inducer of low cell density development. Since nicotinamide is a competitive inhibitor of ADP-ribosyl transferases it has been used to determine whether ADP-ribosylation plays a role in certain biological processes (Williamson \& Moss, 1990). Treatment of retinal rods with nicotinamide caused hyperpolarization and increased flash sensitivity, and suggested that ADP-ribosylation is involved in phototransduction (Falk \& Schloss, 1988). Inhibition of the transferase would lead to the absence of the ADP-ribose modification, which would alter substrate activity. In $M$. xanthus this alteration of activity would then lead to a positive effect on development. Some debate has occurred over the possible physiological role of adenosine during development (Kaiser \& Kroos, 1993). In addition to inducing development of low density cells, adenosine (and other adenine compounds) also induces development in the presence of nutrients (Manoil \& Kaiser, 1980). It has been argued that the latter effect is due to indirect induction of the starvation pathway since ppGpp levels increase in response to adenosine (Manoil \& Kaiser, 1980). Additionally, a mutant resistant to diaminopurine (DK590), which is unresponsive to adenosine, develops normally in response to other inducers such as threonine (Manoil \& Kaiser, 1980). This suggests that adenosine is not required for development. It is not clear, however, how the nutritional over-ride effects of adenosine are related to its cell-density effects.

Kim et al. (1992) have suggested that the efficiency of two developmental signals, the $\mathrm{C}$ - and A-factors, is dependent upon cell density and that this results in the cell-density requirement for $M$. xanthus development. It appears that $M$. xanthus utilizes at least three different cell-density dependent signals, two during early development (Afactor and inhibition of ADP-ribosylation) and one within the constructed aggregate (C-factor). The A-factor and 
the inhibition of ADP-ribosylation either may act via the same pathway or may represent separate cell-densitydependent pathways. The induction of A-factor by the inhibition of ADP-ribosylation can be ruled out since neither adenosine (Kuspa et al., 1992) nor nicotinamide (D. Eastman, unpublished observations) induces A-dependent gene expression. It is possible that the inhibition of ADP-ribosylation is regulated by A-factor or A-factorinduced genes. The second ADP-ribosylation event appears to occur just prior to aggregation and may involve increased ADP-ribosylation of several substrates. The identification of these proteins as putative developmentally regulated ADP-ribosylated substrates suggests that they may play important roles in development. Determining the activities of these substrates and how they may be regulated by ADP-ribosylation could provide a key piece to the puzzle of aggregation and fruiting body development in $M$. xanthus.

\section{ACKNOWLEDGEMENTS}

We thank Dr Donna Fontana for helpful discussions and critical reading of this manuscript. We also thank Kim M. Hildebrandt for technical assistance. This work was supported by NIH grant GM 19957 to M.D.

\section{REFERENCES}

Behmlander, R. \& Dworkin, M. (1991). Extracellular fibrils and contact-mediated cell interactions in Myxococcus xanthus. J Bacteriol 173, 7810-7821.

Brune, B. \& Lapetina, E. G. (1989). Activation of a cytosolic ADPribosyl transferase by nitric oxide generating agents. $J$ Biol Chem 264, 8455-8458.

Burchard, R. P. (1981). Gliding motility of prokaryotes: ultrastructure, physiology, and genetics. Annu Rev Microbiol 35, 497-529.

Chung, D. W. \& Collier, R. J. (1977). The mechanism of ADPribosylation of elongation factor 2 catalyzed by fragment A from diphtheria toxin. Biochim Biophys Acta 483, 248-257.

Duncan, M. R., Rankin, P. R., King, R. L., Jacobson, M. K. \& Dell'Orco, R. T. (1988). Stimulation of mono(ADP-ribosyl)ation by reduced extracellular calcium levels in human fibroblasts. $J$ Cell Pbysiol 134, 161-165.

Dworkin, M. (1963). Nutritional regulation of morphogenesis in Myxococcus xanthus. J Bacteriol 86, 67-72.

Falk, G. \& Schloss, R. A. (1988). Block of light responses of salamander rods by pertussis toxin and reversal by nicotinamide. FEBS Lett 229, 131-134.

Fitzmaurice, W. P., Saari, L. L., Lowery, R. G., Ludden, P. W. \& Roberts, G. P. (1989). Genes coding for the reversible ADPribosylation system of dinitrogenase reductase from $\mathrm{R}$ bodospirillum rubrum. Mol \& Gen Genet 218, 340-347.

Fu, H. R., Burris, H. \& Roberts, G. P. (1990). Reversible ADPribosylation is demonstrated to be a regulatory mechanism in prokaryotes by heterologous expression. Proc Natl Acad Sci USA 87, 1720-1724.

Hagen, D. C., Bretscher, A. P. \& Kaiser, D. (1978). Synergism between morphogenetic mutants of Myxococcus xantbus. Dev Biol 64, 284-296.

Hagen, T. J. \& Shimkets, L. J. (1990). Nucleotide sequence and transcriptional products of the csg locus of Myxococcus xanthus. $J$ Bacteriol 172, 15-23.
Kaiser, D. \& Kroos, L. (1993). Intercellular signalling. In The Myxobacteria II, pp. 257-283. Edited by M. Dworkin \& D. Kaiser. Washington, DC: American Society for Microbiology.

Kim, S. K. \& Kaiser, D. (1990). Purification and properties of Cfactor, an intercellular signaling protein. Proc Natl Acad Sci US A 87, 3635-3639.

Kim, S. K., Kaiser, D. \& Kuspa, A. (1992). Control of cell density and pattern by intercellular signaling in Myxococcus development. Annu Rev Microbiol 1992. 46, 117-139.

Kreimeyer, A., Adamietz, P. \& Hilz, H. (1985). Alkylation-induced mono(ADP-ribosyl)-histones $\mathrm{H} 1$ and H2B. Biol Chem Hoppe-Seyler 366, 537-544.

Kuner, J. M. \& Kaiser, D. (1982). Fruiting body morphogenesis in submerged cultures of Myxococcus xanthus. J Bacteriol 151, 458-461.

Kuspa, A. \& Kaiser, D. (1989). Genes required for developmental signalling in Myxococcus xantbus: three asg loci. J Bacteriol 171, 2762-2772.

Kuspa, A., Kroos, L. \& Kaiser, D. (1986). Intercellular signalling is required for developmental gene expression in Myxococcus xanthus. Dev Biol 117, 267-276.

Kuspa, A., Plamann, L. \& Kaiser, D. (1992). Amino acids and peptides rescue the A-signal-defective developmental mutants of Myxococcus xanthus. J Bacteriol 174, 7360-7369.

Lowery, R. G. \& Ludden, P. W. (1988). Purification and properties of the dinitrogenase reductase inactivating ADP-ribosyltransferase from Rhodospirillum rubrum. J Biol Chem 263, 16714-16719.

Lowery, R. G. \& Ludden, P. W. (1990). Endogenous ADP ribosylation in procaryotes. In ADP-ribosylating Toxins and G-proteins, pp. 459-468. Edited by J. Moss \& M. Vaughan. Washington, DC: American Society for Microbiology.

Lowery, R. G., Saari, L. L. \& Ludden, P. W. (1986). Reversible regulation of the iron protein of nitrogenase from $R$ bodospirillum rubrum by ADP-ribosylation in vitro. $J$ Bacteriol 166, 513-518.

Manoil, C. \& Kaiser, D. (1980). Guanosine pentaphosphate and guanosine tetraphosphate accumulation and induction of Myxococcus xanthus fruiting body development. J Bacteriol 141, 305-315.

Moss, J. \& Vaughan, M. (1978). Isolation of an avian erythrocyte protein possessing ADP-ribosyl transferase activity and capable of activating adenylate cyclase. Proc Natl Acad Sci USA 75, 3621-3624.

Ochi, K., Penyige, A. \& Barabas, G. (1992). The possible role of ADP-ribosylation in sporulation and streptomycin production by Streptomyces griseus. J Gen Microbiol 138, 1745-1750.

O'Farrell, P. H. (1975). High resolution two-dimensional electrophoresis of proteins. J Biol Chem 250, 4007-4021.

Peniyige, A., Barabas, G., Szabo, I. \& Ensign, J. (1990). ADPribosylation of membrane proteins of Streptomyces griseus strain 521. FEMS Microbiol Lett 69, 293-298.

Shimkets, L. J. (1990). Social and developmental biology of the myxobacteria. Microbiol Rev 54, 473-501.

Shimkets, L. J. \& Dworkin, M. (1981). Excreted adenosine is a cell density signal for the initiation of fruiting body formation in Myxococcus xantbus. Dev Biol 84, 51-60.

Spangler, B. D. (1992). Structure and function of cholera toxin and the related Eschericbia coli heat-labile enterotoxin. Microbiol Rev 56, 622-647.

Tao, Y., Howlett, A. \& Klein, C. (1992). Nitric oxide stimulates the ADP-ribosylation of a $41-\mathrm{kDa}$ cytosolic protein in Dictyostelium discoideum. Proc Natl Acad Sci US A 89, 5902-5906.

Ueda, K. \& Hayaishi, O. (1985). ADP-ribosylation. Annu Rev Biochem 54, 73-100. 
Ui, M. (1990). Pertussis toxin as a valuable probe for G-protein involvement in signal transduction. In $A D P$-ribosylating Toxins and G-proteins, pp. 45-77. Edited by J. Moss \& M. Vaughan. Washington, DC: American Society for Microbiology.

Williamson, K. C. \& Moss, J. (1990). Mono-ADP-ribosyltransferases and ADP-ribosylarginine hydrolases: a mono-ADP-ribosylation cycle in animal cells. In $A D P$-ribosylating Toxins and $G$-proteins, pp. 493-510. Edited by J. Moss \& M. Vaughan. Washington, DC: American Society for Microbiology.

Wireman, J.W. \& Dworkin, M. (1975). Morphogenesis and developmental interactions in myxobacteria. Science 189, 516-522.

Received 15 February 1994; revised 23 May 1994; accepted 21 June 1994. 